\title{
TETRONOTHIODIN, A NOVEL CHOLECYSTOKININ TYPE-B RECEPTOR ANTAGONIST PRODUCED BY Streptomyces sp. NR0489
}

\section{TAXONOMY, YIELD IMPROVEMENT AND FERMENTATION}

\author{
Junko Watanabe*, Noriko Fujisaki, Kumtko Fujimori, Yojiro AnZai, \\ Shoichi Oshima, Takashi Sano, Tatsuo Ohtsuka, \\ KimiHiro Watanabe and TORU OKUDA \\ Nippon Roche Research Center, \\ 200 Kajiwara, Kamakura 247, Japan \\ (Received for publication May 15, 1992)
}

\begin{abstract}
Streptomyces sp. NR0489 produces tetronothiodin, a novel brain-type cholecystokinin receptor antagonist. This species was differentiated from its related species S. gelaticus, S. griseolus and $S$. hydrogenans on the basis of their cultural characteristics, such as the utilization of carbohydrates and the presence or absence of various enzymatic activities. We applied the DNA-DNA hybridization method using photobiotin, which proved the genetic difference between the four species mentioned above. The yield improvement effort including single colony isolation, mutation, and protoplast regeneration together with medium optimization resulted in more than an 81 -fold increase of the productivity of tetronothiodin as compared to that of the wild type strain.
\end{abstract}

Using a microbial screen aimed at finding new binding inhibitors of brain-type cholecystokinin (CCK-B) receptors, we discovered a novel antagonist, tetronothiodin, in the fermentation broth of Streptomyces sp. NR0489 ${ }^{1)}$. Since current taxonomic studies on actinomycetes most often require genetic approaches in addition to chemotaxonomy, we applied a DNA-DNA hybridization method using photobiotin which had originally been developed for eubacterial strains. In addition, since yield improvement is often crucial for obtaining a sufficient amount of substances for chemical studies and for biological evaluation, yield improvement and fermentation studies of this strain were also done.

\section{Materials and Methods}

\section{Microorganisms}

The producing organism, strain NR0489 was isolated from a soil sample collected in Kamakura, Kanagawa Prefecture, Japan.

Several strains of Streptomyces (S. gelaticus IFO 12866, S. griseolus IFO 12777, and S. hydrogenans IFO 13475) were used for our comparative taxonomic studies.

\section{Taxonomy}

Methods adopted by the International Streptomyces Project (ISP) ${ }^{2)}$ were used for our taxonomic studies. The cultural characteristics were determined on media recommended by the ISP and WAKSMAN ${ }^{33}$. All cultures were incubated at $27^{\circ} \mathrm{C}$ for 15 days. The names of colors used in our studies were based on the Color Standard of Nippon Shikisai Co., Ltd.

Activities of 19 enzymes were assayed by the API ZYM system (API System S. A., Montalieu Vercieu, France).

The cell wall preparation was obtained by the method of $\mathrm{YAMAGUCH}^{4}{ }^{4}$ and the cell wall contents were analyzed by thin layer chromatography ${ }^{5)}$. Glycolic acid in the cell wall was analyzed by the method of $\mathrm{UCHIDA}^{6\}}$. 
DNA was extracted from the cells by the method of MARMUR ${ }^{7)}$. The guanine plus cytosine content of the DNA was determined by the method of TAMAOKA and KOMAGATA ${ }^{8)}$.

The extent of DNA homology between strains was determined by the fluorometric DNA hybridization method using photobiotin in microdilution wells described by EzAKI ${ }^{91}$. Hybridization was carried out for 2 hours at $55^{\circ} \mathrm{C}$.

\section{Breeding}

We tried a series of breeding experiments to obtain a clone with greater inhibitory activity and more stable productivity. The original clone was mutated with $N$-methyl- $N^{\prime}$-nitro- $N$-nitrosoguanidine (NTG) at pH 9.0 according to Delic et al. ${ }^{10)}$, protoplasts were regenerated as reported by KoJIMA and OKANISHI ${ }^{11}$ and single colonies were isolated in a conventional manner. We altered the composition of the fermentation medium and varied the quantity of each ingredient in order to find an optimum medium for inhibitor production.

\section{Flask Fermentation}

The seed and fermentation medium used in the production of tetronothiodin contained the following: $1.5 \%$ glucose, $0.75 \%$ meat extract, $0.5 \%$ Polypepton, $0.1 \%$ yeast extract, $0.05 \% \mathrm{~K}_{2} \mathrm{HPO}_{4}, 0.05 \%$ $\mathrm{MgSO}_{4} \cdot 7 \mathrm{H}_{2} \mathrm{O}, 0.2 \% \mathrm{CaCO}_{3}, \mathrm{pH} 7.0$. An antifoam (Nissan Disfoam CA-115) was added when necessary.

A slant culture of the strain was inoculated into $100 \mathrm{ml}$ of the seed medium in a $500-\mathrm{ml}$ baffled Erlenmeyer flask. The inoculated medium was cultured on a rotary shaker $(190 \mathrm{rpm})$ at $27^{\circ} \mathrm{C}$ for 3 days. Two $\mathrm{ml}$ of this culture (seed culture) was added to $100 \mathrm{ml}$ of the fermentation medium in a $500-\mathrm{ml}$ baffled Erlenmeyer flask. Fermentation was carried out for 8 days under the same conditions as described above and the inhibitory activity of CCK-B receptor binding by tetronothiodin was assayed.

\section{Jar Fermentation}

The seed culture $(12 \mathrm{ml})$ prepared as described above, was inoculated into $600 \mathrm{ml}$ of the seed medium in each of five 3-liter flasks with baffles. The flasks were shaken at $100 \mathrm{rpm}$ for 3 days at $27^{\circ} \mathrm{C}$. The combined cultures (2.8 liters) were transferred to a 200 -liter jar fermenter containing 140 liters of the fermentation medium. Jar fermentation was carried out at $27^{\circ} \mathrm{C}$ with an agitation rate of $250 \mathrm{rpm}$, air flow rate of 140 liters/minute and internal pressure of $0.5 \mathrm{~kg} / \mathrm{cm}^{2}$. Dissolved oxygen, $\mathrm{pH}$, temperature and agitation speed were automatically monitored every 30 minutes. Inhibitory activity was checked daily. The residual glucose concentration was measured with a glucose analyzer '(Beckman, Model 2). Cell growth was expressed as packed cell volume, which was obtained by centrifugation of $10 \mathrm{ml}$ of cultured broth in a conical tube at $3,500 \mathrm{rpm}$ for 5 minutes.

\section{Results and Discussion}

\section{Taxonomy}

\section{Morphological Characteristics}

The spore chains were the Rectiflexibilis type and each had 20 to 30 spores per chain.

The spores were cylindrical $(0.33 \sim 0.42 \times$ $0.7 \sim 1.1 \mu \mathrm{m})$ and their surface was smooth with some wrinkles (Fig. 1). Sclerotic granules, sporangia and flagellated spores were not observed.

Fragmentation of vegetative mycelium was not observed on any of the agar media tested. When the strain was cultured in a liquid medium such as the fermentation medium on a rotary shaker at $27^{\circ} \mathrm{C}$ for
Fig. 1. Electron micrograph of strain NR0489.

(1/5 Yeast extract-starch agar). Bar represents $1.0 \mu \mathrm{m}$.

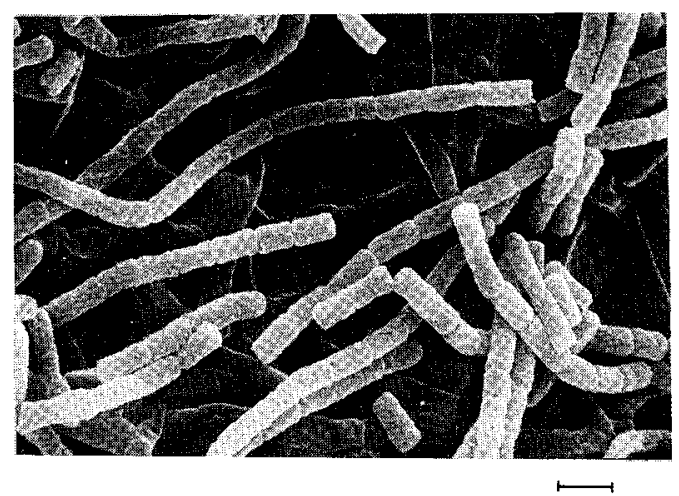


Table 1. Cultural characteristics of strain NR0489, Streptomyces gelaticus IFO 12866, Streptomyces griseolus IFO 12777, and Streptomyces hydrogenans IFO 13475.

\begin{tabular}{|c|c|c|c|c|c|}
\hline Medium & & NR0489 & S. gelaticus IFO 12866 & S. griseolus IFO 12777 & S. hydrogenans IFO 13475 \\
\hline \multirow{4}{*}{$\begin{array}{l}\text { Sucrose - nitrate agar } \\
\text { (Waksman medium } \\
\text { No. 1) }\end{array}$} & $\mathrm{G}:$ & Moderate, colorless & Poor, colorless & Poor, colorless & Poor, colorless \\
\hline & AM: & Thin, white & Thin, white & Thin, white & Thin, whitish gray \\
\hline & $\mathrm{R}:$ & Colorless & Colorless & Colorless & Colorless \\
\hline & SP: & None & None & None & None \\
\hline \multirow{4}{*}{$\begin{array}{l}\text { Yeast extract - malt } \\
\text { extract agar } \\
\text { (ISP medium No. 2) }\end{array}$} & $\mathrm{G}:$ & Good, colorless & Good, colorless & Good, grayish yellow brown & Good, colorless \\
\hline & AM: & Abundant, white $\sim$ light gray & Scant, brownish white & Abundant, white gray & Thin, light gray \\
\hline & $\mathrm{R}:$ & Dull yellow orange & Dull yellow orange & Brownish gray & Colorless \\
\hline & SP: & None & None - & None & None \\
\hline \multirow{4}{*}{$\begin{array}{l}\text { Oatmeal agar } \\
\quad(\text { ISP medium No. 3) }\end{array}$} & $\mathrm{G}:$ & Moderate, colorless & Moderate, colorless & Good, brownish gray & Good, colorless \\
\hline & AM: & Thin, white $\sim$ light gray & Scant, white & Moderate, white $\sim$ light gray & Thin, light gray \\
\hline & $\mathrm{R}:$ & Colorless & Colorless & Brownish gray & Colorless \\
\hline & SP: & None & None & Pale yellowish brown & Pale yellowish brown \\
\hline \multirow{4}{*}{$\begin{array}{l}\text { Inorganic salts - starch } \\
\text { agar } \\
\text { (ISP medium No. 4) }\end{array}$} & G: & Moderate, colorless & Good, colorless & Good, pale yellowish brown & Good, pale yellowish brown \\
\hline & AM: & Thin, grayish white $\sim$ light gray & Scant, white & Moderate, white $\sim$ light gray & Thin, light brownish gray \\
\hline & $\mathrm{R}:$ & Colorless & Pale yellowish brown & Light brownish gray & Light brownish gray \\
\hline & SP: & None & None & None & None \\
\hline \multirow{4}{*}{$\begin{array}{l}\text { Glycerol - asparagine agar } \\
\text { (ISP medium No. 5) }\end{array}$} & G: & Poor, colorless & Good, colorless & Good, colorless & Good, colorless \\
\hline & AM: & Thin, brownish white & Thin, brownish white & Abundant, white & Abundant, light brownish gray \\
\hline & $\mathrm{R}$ : & Brownish white & Pale yellowish brown & Pale yellowish brown & Light brownish gray \\
\hline & SP: & None & Pale yellow orange & Pale yellow orange & None \\
\hline \multirow{4}{*}{$\begin{array}{l}\text { Glucose - asparagine agar } \\
\text { (Waksman medium } \\
\text { No. 2) }\end{array}$} & G: & Good, brownish white & Good, brownish white & Good, light brownish gray & Good, pale yellowish brown \\
\hline & AM: & Abundant, white $\sim$ light gray & Scant, brownish white & Moderate, white $\sim$ brownish gray & Scant, light gray \\
\hline & $\mathrm{R}:$ & Brownish white & Brownish white & Pale yellowish brown & Pale yellowish brown \\
\hline & SP: & None & None & None & Yellowish brown \\
\hline \multirow{4}{*}{$\begin{array}{l}\text { Tyrosine agar } \\
\text { (ISP medium No. 7) }\end{array}$} & G: & Good, pale yellowish brown & Good, pale yellowish brown & Moderate, light brownish gray & Good, pale yellowish brown \\
\hline & AM: & Moderate, white & Scant, white & Moderate, light brownish gray & Thin, light gray \\
\hline & $\mathrm{R}:$ & Pale yellowish brown & Pale yellowish brown & Pale yellowish brown & Pale yellowish brown \\
\hline & SP: & None & Pale yellowish brown & None & None \\
\hline \multirow{4}{*}{$\begin{array}{l}\text { Nutrient agar } \\
\text { (Waksman medium } \\
\text { No. 14) }\end{array}$} & G: & Good, colorless & Good, colorless & Moderate, colorless & Good, colorless \\
\hline & AM: & None & None & Moderate, white & Thin, brownish white \\
\hline & $\mathrm{R}:$ & Colorless & Colorless & Colorless & Colorless \\
\hline & SP: & None & None & None & None \\
\hline
\end{tabular}

Abbreviations: G, growth; AM, aerial mycelium; R, reverse side color; S, soluble pigment. 
3 days, however, it formed submerged spore-like bodies.

\section{Cultural Characteristics}

The cultural characteristics of strain NR0489 on various media are summarized in Table 1. Yeast extract - malt extract agar and glucose - asparagine agar supported the best growth and provided abundant formation of aerial mycelia.

Aerial mass color was in the gray color series. Pigmentation of the substrate mycelia was not distinctive. No soluble pigment was observed.

\section{Physiological Characteristics}

The physiological characteristics and the utilization of carbohydrate are shown in Tables 2 and 3, respectively. Hydrolysis of gelatin, starch, and milk were negative, nitrate reduction was positive, $\mathrm{H}_{2} \mathrm{~S}$ production was negative and melanoid pigment was not produced. Strain NR0489 did not grow on yeast extract - malt extract agar supplemented with $4 \% \mathrm{NaCl}$. This strain used cellobiose, D-fructose, D-galactose, D-glucose, lactose, maltose, D-mannose, melibiose, L-rhamnose, salicin, trehalose and D-xylose as sole carbon sources.

This strain grew within a temperature range of $20^{\circ} \mathrm{C}$ to $37^{\circ} \mathrm{C}$, with an optimum temperature range of $27^{\circ} \mathrm{C}$ to $30^{\circ} \mathrm{C}$.

Activities of 19 enzymes by the API ZYM system are shown in Table 4.

\section{Chemotaxonomic Characteristics}

Whole cell hydrolysates of strain NR0489 contained LL-diaminopimelic acid but no mesodiaminopimelic acid. Glycine was detected in the cell wall. Therefore it was placed in the Type I cell wall group of LeCHEVALIER et al.

The glycolate test was negative. The DNA from strain NR0489 contained $72.3 \mathrm{~mol} \%$ guanine plus cytosine.

Table 2. Physiological characteristics of strain NR0489, Streptomyces gelaticus IFO 12866, Streptomyces griseolus IFO 12777, and Streptomyces hydrogenans IFO 13475.

\begin{tabular}{lcccc}
\hline & NR0489 & $\begin{array}{c}\text { S. gelaticus } \\
\text { IFO 12866 }\end{array}$ & $\begin{array}{c}\text { S. griseolus } \\
\text { IFO 12777 }\end{array}$ & $\begin{array}{c}\text { S. hydrogenans } \\
\text { IFO } 13475\end{array}$ \\
\hline Gelatin liquefaction & - & - & + & - \\
Starch hydrolysis & - & + & + & + \\
Milk coagulation at $27^{\circ} \mathrm{C}$ & - & - & - & - \\
Milk peptonization at $27^{\circ} \mathrm{C}$ & - & + & + & + \\
Nitrate reduction & + & - & - & - \\
$\mathrm{H}_{2}$ S production & - & - & - & - \\
Melanin production & - & - & - & - \\
ISP medium No. 1 & - & - & - & - \\
ISP medium No. 6 & $<4 \%$ & $\leq 7 \%$ & $\leq 7 \%$ & $<7 \%$ \\
ISP medium No. 7 & $20 \sim 37^{\circ} \mathrm{C}$ & $10 \sim 37^{\circ} \mathrm{C}$ & $10 \sim 37^{\circ} \mathrm{C}$ & $20 \sim 37^{\circ} \mathrm{C}$ \\
NaCl tolerance & $27 \sim 30^{\circ} \mathrm{C}$ & $27 \sim 30^{\circ} \mathrm{C}$ & $20 \sim 27^{\circ} \mathrm{C}$ & $27 \sim 30^{\circ} \mathrm{C}$ \\
Temperature range for growth & & & &
\end{tabular}

+ , Positive; - , negative. 
Table 3. Carbohydrate utilization of strain NR0489, Streptomyces gelaticus IFO 12866, Streptomyces griseolus IFO 12777, and Streptomyces hydrogenans IFO 13475 .

\begin{tabular}{lcccc}
\hline & NR0489 & $\begin{array}{c}\text { S. gelaticus } \\
\text { IFO } 12866\end{array}$ & $\begin{array}{c}\text { S. griseolus } \\
\text { IFO } 12777\end{array}$ & $\begin{array}{c}\text { S. hydrogenans } \\
\text { IFO 13475 }\end{array}$ \\
\hline Adonitol & - & + & - & - \\
L-Arabinose & - & - & + & + \\
Cellobiose & + & + & + & + \\
D-Fructose & + & - & + & + \\
D-Galactose & + & + & + & + \\
D-Glucose & + & + & + & + \\
Glycerol & - & + & - & + \\
Inositol & - & - & + & + \\
Lactose & + & + & - & + \\
Maltose & + & + & + & + \\
D-Mannitol & - & + & - & - \\
D-Mannose & + & - & - & - \\
Melezitose & - & - & - & + \\
Melibiose & + & + & - & + \\
Rafinose & - & \pm & + & + \\
L-Rhamnose & + & \pm & + & + \\
Salicin & + & + & + & + \\
Sucrose & + & + & + & + \\
Trehalose & + & + & + & + \\
D-Xylose & + & + & + & + \\
\hline & & + & + & + \\
\hline
\end{tabular}

Table 4. Enzymatic activity in strain NR0489, Streptomyces gelaticus IFO 12866 , Streptomyces griseolus IFO 12777, and Streptomyces hydrogenans IFO 13475.

\begin{tabular}{|c|c|c|c|c|}
\hline Enzyme assayed for & NR0489 & $\begin{array}{l}\text { S. gelaticus } \\
\text { IFO } 12866\end{array}$ & $\begin{array}{l}\text { S. griseolus } \\
\text { IFO } 12777\end{array}$ & $\begin{array}{l}\text { S. hydrogenans } \\
\text { IFO } 13475\end{array}$ \\
\hline Alkaline phosphatase & + & + & + & + \\
\hline Esterase (butyrate) & + & - & + & - \\
\hline Esterase (caprylate) & + & + & + & + \\
\hline Lipase (myristate) & + & - & + & - \\
\hline Leucine arylamidase & + & + & + & + \\
\hline Valine arylamidase & + & + & + & + \\
\hline Cystine arylamidase & + & + & + & + \\
\hline Trypsin & + & + & + & - \\
\hline$\alpha$-Chymotrypsin & - & + & + & + \\
\hline Acid phosphatase & + & + & + & + \\
\hline Phosphoamidase & + & + & + & + \\
\hline$\alpha$-D-Galactosidase & - & + & + & - \\
\hline$\beta$-D-Galactosidase & + & + & + & + \\
\hline$\beta$-D-Glucuronidase & - & - & - & - \\
\hline$\alpha-D-G l u c o s i d a s e$ & + & + & + & + \\
\hline$\beta$-D-Glucosidase & + & + & + & + \\
\hline $\begin{array}{l}N \text {-Acetyl- } \beta \text {-D- } \\
\text { glucosaminidase }\end{array}$ & + & + & + & + \\
\hline$\alpha$-D-Mannosidase & - & + & - & - \\
\hline$\alpha$-L-Fucosidase & - & - & - & - \\
\hline
\end{tabular}

Determination of the Taxonomic Position of Strain NR0489

Based on the taxonomic characteristics described above, we assigned strain NR0489 to the genus Streptomyces. Among the known species of this genus, our strain showed some resemblance to $S$. gelaticus 
Waksman \& Henrici $^{12)}$, S. griseolus Waksman \& Henrici ${ }^{13)}$, and S. hydrogenans Lindner, Junk, Nesemann \& Schmidt-Thomé ${ }^{14}$. The microbiological characteristics of strain NR0489 were compared with those of the type cultures obtained from IFO and were found to differ clearly from the other species with respect to the properties below. The comparative studies are shown in Tables 1 to 4 .

The cultural characteristics of strain NR0489 grown on most media, except for sucrose-nitrate agar and nutrient agar, were different from those of Streptomyces gelaticus.

Strain NR0489 grown on yeast extract-malt extract agar and glucose-asparagine agar formed abundant aerial mycelia, whereas $S$. gelaticus grown on any of the media formed poor aerial mycelia.

Starch hydrolysis, milk peptonization, nitrate reduction and $\mathrm{NaCl}$ tolerance of strain NR0489 were different from those of S. gelaticus. Our strain and S. gelaticus also showed different patterns of carbohydrate utilization and enzymatic activity.

Aerial mycelium formation, and pigmentation of the substrate mycelia of strain NR0489 and Streptomyces griseolus grown on sucrose - nitrate agar, tyrosine agar and nutrient agar were similar, but when both were grown on all other media they were different.

S. griseolus sporulated more abundantly on most media than did strain NR0489.

The carbohydrate utilization pattern, gelatin liquefaction, starch hydrolysis, milk peptonization and $\mathrm{NaCl}$ tolerance of strain NR0489 were different from those of $S$. griseolus. But the enzymatic activity patterns of both were similar.

Aerial mycelium formation and pigmentation of the substrate mycelia of strain NR0489 and Streptomyces hydrogenans were similar on sucrose - nitrate agar, tyrosine agar and nutrient agar, but were different on all other media. Moreover, $S$. hydrogenans formed a brown soluble pigment on glucose - asparagine agar while strain NR0489 did not.

The carbohydrate utilization patterns of strain NR0489 and S. hydrogenans were similar, but starch hydrolysis, milk peptonization and $\mathrm{NaCl}$ tolerance of each were different. The enzymatic activity pattern of strain NR0489 was different from that of S. hydrogenans.

$S$. hydrogenans formed submerged spore-like bodies when grown in fermentation medium on a rotary shaker at $27^{\circ} \mathrm{C}$ for 3 days as strain NR0489 did, however the other two cultures did not.

The results of the above phenotypic comparison indicated that strain NR0489 was clearly different from the other species.

We carried out DNA-DNA hybridization to confirm this conclusion. EZAKr et al. ${ }^{9}$ have described the fluorometric DNA-DNA hybridization in microtiter wells using photobiotin instead of radioisotope and nick translation. This method was originally developed for the determination of genetic relatedness

Table 5. DNA relatedness between strain NR0489, S. gelaticus IFO 12866, S. griseolus IFO 12777, and $S$. hydrogenans IFO 13475.

\begin{tabular}{lcccc}
\hline \multirow{2}{*}{ Strain } & \multicolumn{3}{c}{$\%$ Homology with photobiotin-labeled DNA } \\
\cline { 2 - 5 } & NR0489 & IFO 12866 & IFO 12777 & IFO 13475 \\
\hline NR0489 & 100 & & & \\
S. gelaticus IFO 12866 & 5.0 & 100 & & \\
S. griseolus IFO 12777 & 10.5 & 22.3 & 100 & 100 \\
S. hydrogenans IFO 13475 & 5.7 & 14.3 & 7.9 & 1 \\
\hline
\end{tabular}

DNA homology values are expressed as \% of labeled DNA reassociated with heterologous DNA compared with that reassociated with homologous DNA (100\%). 
between eubacterial strains. We applied this method to actinomycete strains of NR0489 and those species mentioned above.

Homology values between strain NR0489 and S. gelaticus, S. griseolus and S. hydrogenans were 5.0\%, $10.5 \%$ and $5.7 \%$, respectively (shown in Table 5). Therefore strain NR0489 was clearly unrelated to these species from a genetic point of view.

We finally concluded that our strain is a different species from them and assigned it to be Streptomyces sp. NR0489.

In addition, we also confirmed that $S$. gelaticus, $S$. griseolus and $S$. hydrogenans were genetically unrelated, and that they were distinct species. This supported the results of S. T. WiLliams ${ }^{15}$.

\section{Breeding}

Since the original productivity $\left(\mathrm{IC}_{50}: 0.36 \%\right.$ ) was not enough for further chemical and biological evaluation, yield improvement trials were necessary.

We examined a series of single spore cultures to obtain greater inhibition of CCK-B receptor binding and uniform production. We thus obtained a clone $1 \mathrm{SC} 20$ showing an $\mathrm{IC}_{50}$ of $0.095 \%$ selected from 100 strains. Although this clone showed uniform productivity, it was not enough for purification of the inhibitor. After repeated NTG mutation trials, we obtained clone $2 \mathrm{~N} 17$ which showed an $\mathrm{IC}_{50}$ of $0.060 \%$. The protoplast regeneration method was applied to stabilize productivity, resulting in clone $1 \mathrm{P} 81$, which showed a 16-fold greater productivity ( $\mathbf{I C}_{50}: 0.022 \%$ ) than that of the wild type strain (Fig. 2).

Fig. 2. Breeding of strain NR0489.

Wild type strain NR0489 $(0.36)^{2}$

Single colony isolation

$1 \mathrm{SC} 20(0.095)$

NTG mutation

1N13(0.11)

NTG mutation

$2 \mathrm{~N} 17(0.060)$

Protoplast regeneration

1 P81 (0.022)

a $\mathrm{IC}_{50}$ values determined by the previously reported method $^{11}$.

Table 6. Effect of nitrogen sources on production.

\begin{tabular}{lc|lc}
\hline $\begin{array}{c}\text { Nitrogen source } \\
\text { (concentration: 1\%) }\end{array}$ & $\begin{array}{c}\% \text { Inhibition at } \\
0.3 \% \text { broth in the } \\
\text { assay mixture }\end{array}$ & $\begin{array}{c}\text { Nitrogen source } \\
\text { (concentration: 1\%) }\end{array}$ & $\begin{array}{c}\text { \% Inhibition at } \\
0.3 \% \text { broth in the } \\
\text { assay mixture }\end{array}$ \\
\hline Ajipron E3 (Ajinomoto) & 5 & Polypepton (Nihon Seiyaku) & 70 \\
Medium ingredient S (Yukijirushi) & 6 & Proteose peptone (Difco) & 47 \\
Casamino acids (Difco) & 80 & Rapeseed cake (Nisshin Seiyu) & 24 \\
Casitone (Difco) & 90 & Skim milk (Difco) & 12 \\
Corn meal (Kishimoto Sangyo) & 26 & Toast soya (Nisshin Seiyu) & 24 \\
Corn steep liquor (Hohnen Seiyu) & 29 & Totamin S (Kishimoto Sangyo) & 14 \\
Soy peptide hainutoh S (Fuji Seiyu) & 15 & Tryptone (Difco) & 60 \\
G powder (Fish meal; Yaizu Suisan) & 20 & Tryptose (Difco) & 67 \\
Kinako & 25 & Yeast extract (Nihon Seiyaku) & 70 \\
Malt extract (Difco) & 26 & Yeast extract (Oriental) & 84 \\
Meat extract (Kyokuto Seiyaku) & 69 & Yeast extract (Difco) & 73 \\
Meat extract (Yaizu Suisan) & 82 & Fresh yeast (Oriental) & 89 \\
Meat extract (Kishimoto Sangyo) & 22 & & 69 \\
NZ-amine (Sheffield) & 83 & & 23 \\
Pharmamedia (Traders protein) & 13 & & \\
\hline
\end{tabular}


Medium Improvement

Although the production of tetronothiodin by the clone in flask culture was high enough, its production in jar fermentation was not always successful because of rather poor growth and delayed production. We thus examined the influence of medium components. The effect of glucose, glycerol, maltose, dextrin, soluble starch, xylose, fructose and rhamnose as carbon sources was examined. Glucose gave the best result. The concentration of glucose and the effect of an additional carbon source were also examined. The addition of $1.5 \%$ glucose was optimal for production. A higher concentration of glucose caused delayed production of tetronothiodin.

The production of tetronothiodin by the clone grown on twenty-nine different nitrogen sources was examined. Among them, Casitone, yeast extract, NZ-amine, Polypepton, Casamino acids and meat extract were particularly effective (Table 6). In order to determine the effect of amino acids on production, we

Table 7. Effect of amino acids on production.

\begin{tabular}{cc|cc}
\hline $\begin{array}{c}\text { Amino acid } \\
\text { (concentration: } 0.2 \%)\end{array}$ & $\begin{array}{c}\% \text { Inhibition at } 0.2 \% \\
\text { broth in the assay mixture }\end{array}$ & $\begin{array}{c}\text { Amino acid } \\
\text { (concentration: } 0.2 \%)\end{array}$ & $\begin{array}{c}\% \text { Inhibition at } 0.2 \% \\
\text { broth in the assay mixture }\end{array}$ \\
\hline L-Alanine & 85 & L-Lysine & 16 \\
& $(0.0044)$ & L-Methionine & 20 \\
L-Arginine & 2 & L-Phenylalanine & 49 \\
L-Asparagine & 23 & L-Proline & 79 \\
L-Aspartic acid & 40 & L-Serine & $(0.0072)$ \\
L-Cysteine & 3 & L-Threonine & 56 \\
L-Glutamine & 5 & & $(0.019)$ \\
Sodium L-glutamate & 76 & L-Tryptophan & 74 \\
Glycine & $(0.010)$ & L-Tyrosine & 59 \\
L-Histidine & 80 & L-Valine & 84 \\
L-Isoleucine & $(0.014)$ & & $(0.0061)$ \\
L-Leucine & 36 & & \\
\hline
\end{tabular}

( ): $\mathrm{IC}_{50} \%$.

Fig. 3. Time course of tetronothiodin fermentation in a 200 -liter fermenter.

Glucose, $\bullet \mathrm{pH}, \square$ inhibition, a packed cell volume.

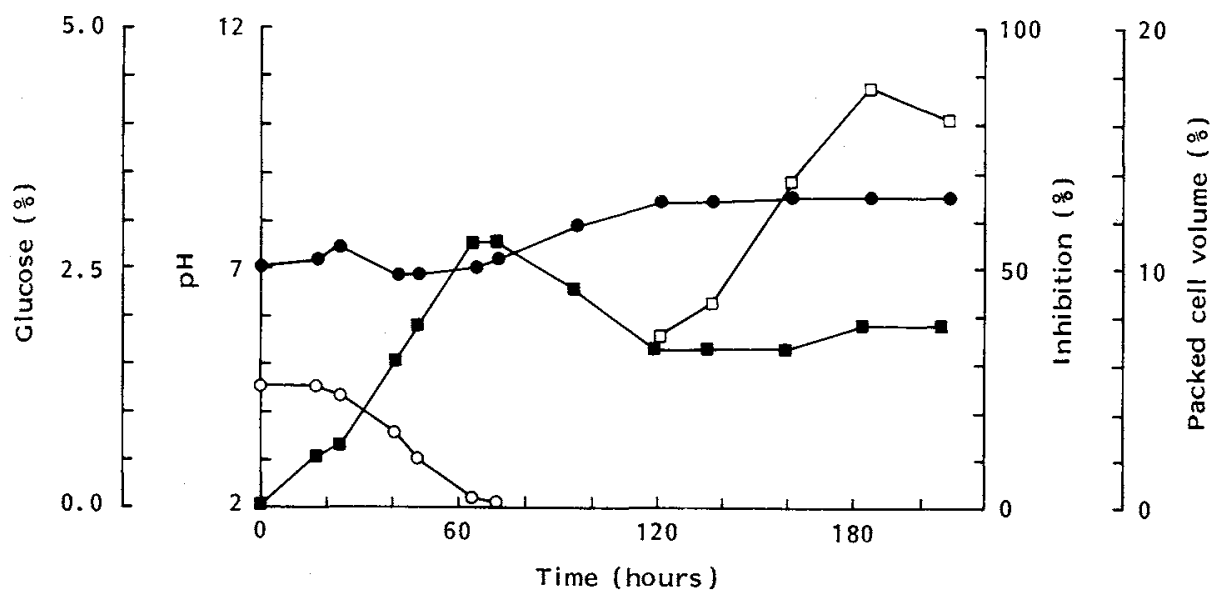


added one of each of 20 amino acids (as the sole nitrogen source) to the production medium. Table 7 indicates that L-alanine, L-glutamic acid, glycine, L-isoleucine, L-leucine, L-proline, L-threonine, L-tryptophan and L-valine were effective, while sulfur-containing or basic amino acids such as L-cysteine, $\mathrm{L}$-arginine and L-methionine were not. Among all the amino acids tested, $\mathrm{L}$-alanine and L-leucine each as the sole nitrogen source resulted in optimal productivity, showing an $\mathrm{IC}_{50}$ of $0.0044 \%$. We successfully obtained an 81-fold increase in productivity by clone 1P81 in the optimal medium compared to that of the wild type strain.

Fig. 4. Time course of tetronothiodin fermentation in a 50-liter fermenter.

(A) Batch culture, (B) fed-batch culture, $\bullet$ glucose, $O$ inhibition, $\triangle$ packed cell volume (PCV), $\square \mathrm{pH}, \square$ dissolved oxygen (DO), $\triangle \mathrm{CO}_{2}$.

(A)
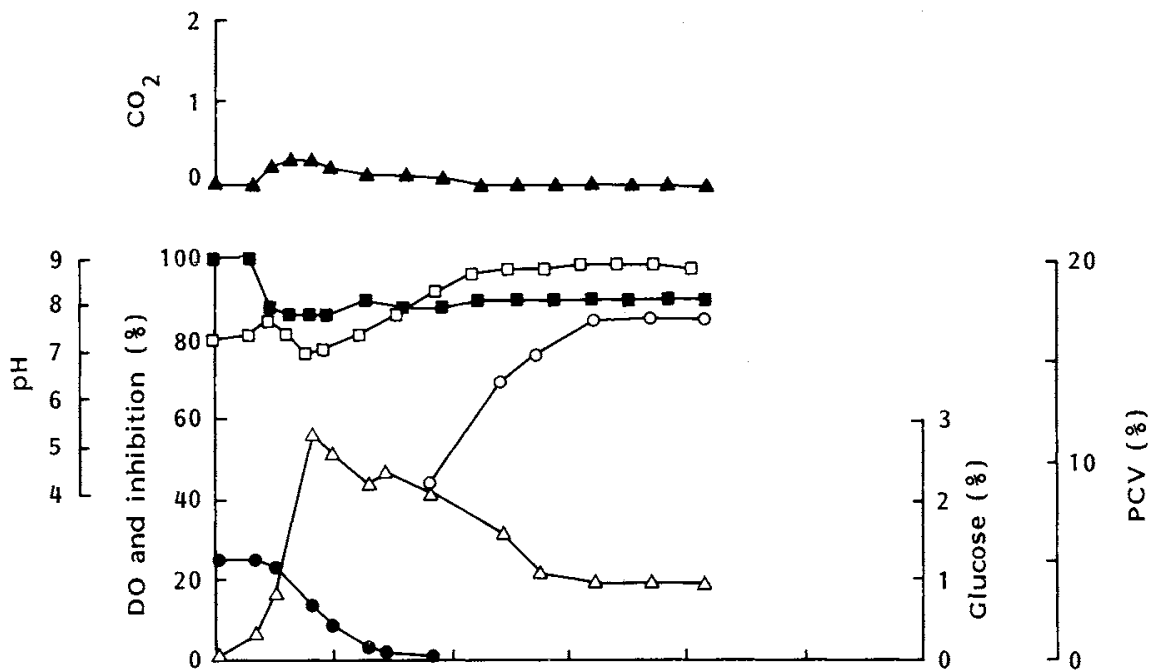

(B)
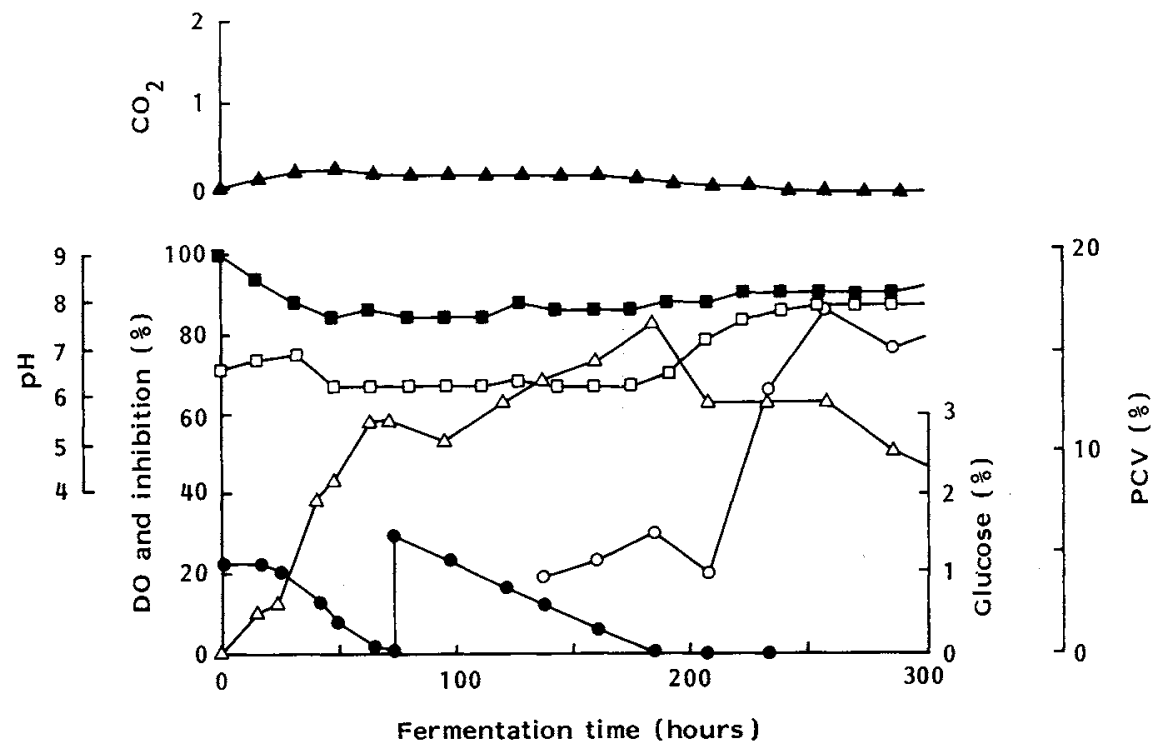
Jar Fermentation

A typical time course of tetronothiodin production in a 200 -liter jar fermenter is shown in Fig. 3 . The $\mathrm{pH}$ was the lowest during the $40 \sim 60$-hour period and glucose was still being consumed after 60 hours of fermentation. Cells grew exponentially until around 80 hours of fermentation. After the glucose was almost exhausted with the accompanying decrease in cell growth, the production of tetronothiodin began. It reached its maximum after 185 hours of fermentation. This indicated typical production of secondary metabolites.

According to the fed batch culture experiment shown in Fig. 4, the addition of glucose after the depletion of carbon sources resulted in the delayed production (250 hours of fermentation) of tetronothiodin, which was most probably due to catabolite repression.

Acknowledgments

The authors are grateful to Mr. T. KUDOH and Ms. A. NAKano for the assay of tetronothiodin.

\section{References}

1) Ohtsuka, T.; K. Kudoh, N. Shimma, H. Kotaki, N. Nakayama, Y. Itezono, N. Fujisaki, J. Watanabe, K. YOKOSE \& H. SETO: Tetronothiodin, a novel cholecystokinin type-B receptor antagonist produced by Streptomyces sp. J. Antibiotics 45: $140 \sim 143,1992$

2) Shirling, E. B. \& D. Gottlieb: Methods for characterization of Streptomyces species. Int. J. Syst. Bacteriol. 16 $313 \sim 340,1966$

3) Waksman, S. A. $(E d$.$) : The Actinomycetes. Vol. 2. Classification, Identification and Description of Genera and$ Species. Williams \& Wilkins Co., 1961

4) Yamaguchi, T.: Comparison of the cell-wall composition of morphologically distinct actinomycetes. J. Bacteriol. 89: $444 \sim 453,1965$

5) StAneck, J. L. \& G. D. RoberTs: Simplified approach to identification of aerobic actinomycetes by thin-layer chromatography. Appl. Microbiol. 28: 226 231, 1974

6) Uchida, K.: Cell-wall acyl type in actinomycetes, its simple identification by glycolate test. The Actinomycetologist No. 40: $28 \sim 31,1982$

7) Marmur, J.: A procedure for the isolation of deoxyribonucleic acid from micro-organisms. J. Mol. Biol. 3: $208 \sim 218,1961$

8) TamaOKA, J. \& K. Komagata: Determination of DNA base composition by reversed-phase high-performance liquid chromatography. FEMS Microbiol. Lett. 25: 125 128, 1984

9) EzaKi, T.; Y. Hashimoto \& E. YABUUCHI: Fluorometric deoxyribonucleic acid-deoxyribonucleic acid hybridization in microdilution wells as an alternative to membrane filter hybridization in which radioisotopes are used to determine genetic relatedness among bacterial strains. Int. J. Syst. Bacteriol. 39: $224 \sim 229$, 1989

10) Delic, V.; D. Hopwood \& E. FRIEND: Mutagenesis by $N$-methyl- $N^{\prime}$-nitro- $N$-nitrosoguanidine (NTG) in Streptomyces coelicolor. Mutation Res. 9: 167 182, 1970

11) Kojima, I. \& M. OKanishi: Cell fusion of actinomycetes. The Actinomycetologist No. 40: 12 27, 1982

12) Shirling, E. B. \& D. Gottlieb: Cooperative description of type cultures of Streptomyces. III. Additional species descriptions from first and second studies. Int. J. Syst. Bacteriol 18: 279 392, 1968

13) Shirling, E. B. \& D. Gottlieb: Cooperative description of type cultures of Streptomyces. II. Species descriptions from first study. Int. J. Syst. Bacteriol. 18: 69 189, 1968

14) Shirling, E. B. \& D Gottlieb: Cooperative description of type strains of Streptomyces. V. Additional descriptions. Int. J. Syst. Bacteriol. 22: 265 394, 1972

15) Williams, S. T.; M. Goodfellow \& G. Alderson: Genus Streptomyces Waksman and Henrichi 1943, 339 AL. In BERGEY's Manual of Systematic Bacteriology. Volume 4. Ed., S. T. Williams et al., pp. 2452 2492, Williams \& Willkins Co., 1989 